\title{
WASTE HEAT RECOVERY IN HEAT PUMP SYSTEMS: SOLUTION TO REDUCE GLOBAL WARMING
}

\author{
Y. BARADEY, M.N.A. HAWLADER, AHMAD FARIS ISMAIL AND MEFTAH HraIRI \\ Department of Mechanical Engineering, Faculty of Engineering' \\ International Islamic University Malaysia, \\ Jalan Gombak, 53100, Kuala Lumpur, Malaysia.
}

yehyabaradei@yahoo.com,mehawlader@iium.edu.my,faris@iium.edu.my,and

meftah@iium.edu.my

(Received: October 5, 2015; Accepted: October 30, 2015; Published on-line: November 30, 2015)

\begin{abstract}
Energy conversion technologies, where waste heat recovery systems are included, have received significant attention in recent years due to reasons that include depletion of fossil fuel, increasing oil prices, changes in climatic conditions, and global warming. For low temperature applications, there are many sources of thermal waste heat, and several recovery systems and potential useful applications have been proposed by researchers [1-4]. In addition, many types of equipment are used to recover waste thermal energy from different systems at low, medium, and high temperature applications, such as heat exchangers, waste heat recovery boiler, thermo-electric generators, and recuperators. In this paper, the focus is on waste heat recovery from air conditioners, and an efficient application of these energy resources. Integration of solar energy with heat pump technologies and major factors that affect the feasibility of heat recovery systems have been studied and reviewed as well.
\end{abstract}

ABSTRAK: Teknologi penukaran tenaga, di mana sistem pemulihan haba buangan diambil kira, mula mendapat perhatian kebelakangan ini disebabkan oleh beberapa faktor. Contohnya kurangnya tenaga fosil, peningkatan harga minyak, perubahan cuaca dan pemanasan global. Pada aplikasi suhu rendah, terdapat banyak sumber haba buangan dan beberapa sistem pemulihan dan aplikasi berguna yang sesuai dicadangkan oleh pelbagai pengkaji dari seluruh dunia [1-4]. Tambahan pula, berbagai alatan digunakan untuk memulihkan tenaga haba buangan daripada sistem yang berbeza kepada aplikasi suhu rendah, sederhana dan tinggi. Alatan tersebut meliputi penukar haba, dandang pemulihan tenaga haba buangan, penjana elektrik-terma dan pemulih. Kertas kerja ini memfokuskan kepada pemulihan tenaga haba buangan daripada penghawa dingin dan aplikasi yang efisien bagi sumber tenaga ini. Turut dikaji juga, gabungan tenaga suria bersama teknologi pam haba dan faktor utama yang mempengaruhi kebolehlaksanaan sistem pemulihan tenaga haba.

KEYWORDS: waste heat recovery; heat pump.

\section{INTRODUCTION}

Generally, sustainability, safety, innovation, and energy conservation have recently become the most attractive and significant goals especially in modern societies. According to Senda [1], energy conservation coupled with waste heat recovery has become an attractive topic for research in industrialized countries since the begining of the twenty first century. This started in the seventies due to the fact that oil is a finite energy source, 
with significant increases in its price, and political conflicts associated with it. Increasing the cost of fuel has a great effect on the running cost of fuel based systems. In vehicles, for instance, air conditioning systems adds up to $35 \%$ in extra cost [2]. Hence reduction in air condition load by exploiting the waste heat from the engine will lead to significant reduction in the vehicle's fuel consumption. In addition, huge increase in oil production and usage during the last century has caused climatic changes and problem such as global warming and ozone depletion.

A comparison between the main cause of global warming, which is carbon dioxide gas emission, and energy consumption in Australia has been made, as shown in Figure1. From the figure it is observed that gas fired heat pumps consume energy double than that of electric heat pumps while the percentage of carbon dioxide emission is about half $(0.42)$.

However, due to the economic issues with regards to saving energy, waste heat recovery, has also become significantly more important. After signing the Kyoto Protocol on Climate Change in 1997, the world has been moving towards embracing renewable energy resources, particularly solar energy, wind energy, and biomass energy together with paying great attention on saving energy and waste heat recovery systems WHR.

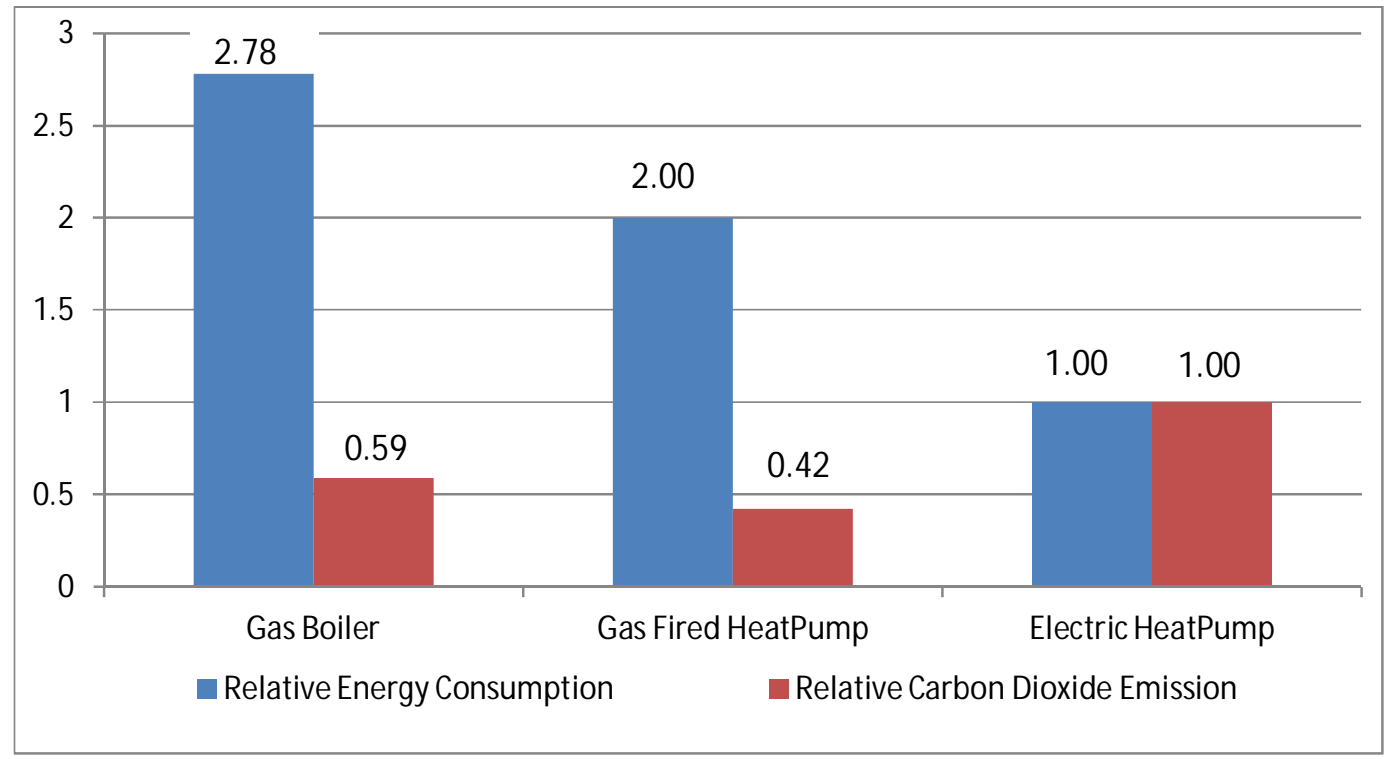

Fig. 1: Comparison between energy consumption and $\mathrm{CO}_{2}$ emission in Australia.

For example, the relationship between electric heat pump and $\mathrm{CO}_{2}$ heat pump is 1:1 [3].

Energy intensive industries have for many decades used waste heat recovery systems for either energy reuse or storage [1]. The wasted heat is transferred into an energy conversion system using different types of heat recovery equipment. The waste heat recovery concept requires efforts in preventing potential energy losses of any kind. It includes, for instance, designing and implementing useful and efficient systems to recover the wasted heat from air conditioning systems, thermal insulation to increase thermal system efficiencies, exploitation of heat losses from furnaces and vehicle engines, and repair of steam leaks in power plants. Once the requirements are achieved, suitable strategies have to be made to stabilize short- term energy saving and or/ energy recovery in systems using permanent solutions for implementation [4]. These permanent solutions are commonly termed heat recovery systems. 
Different methods are used for recovering industrial waste heat. Wasted heat can be either used in different processes for the same systems, such as wasted heat from a heat pump system exploited and used, by re-designing the pipe line for water heating within the same system, or can be re-used in same processes like using the hot exhaust gases from combustion to preheat combustion air in industrial boilers. Table 1 reflects some resources of waste heat [5]. This paper focuses on recovery of dissipated heat from air conditioners (heat pump systems) and its potential useful applications.

Table 1: Some of waste heat sources.

\begin{tabular}{|c|c|}
\hline \multicolumn{2}{|c|}{ Waste Heat Sources } \\
\hline Combustion exhausts: & $\begin{array}{l}\text { - Glass melting furnace } \\
\text { - Cement kiln } \\
\text { - Fume incinerator } \\
\text { - Aluminium reverberatory furnace } \\
\text { - Boiler }\end{array}$ \\
\hline Process off gases: & $\begin{array}{l}\text { - Steel electric arc furnace } \\
\text { - Aluminum reverberatory furnace }\end{array}$ \\
\hline Cooling water from: & $\begin{array}{l}\text { - Furnaces air compressors } \\
\text { - Internal combustion engines }\end{array}$ \\
\hline $\begin{array}{l}\text { Conductive, convective, and radiative losses } \\
\text { from equipment: }\end{array}$ & - Hall-Hèroult cells \\
\hline $\begin{array}{l}\text { Conductive, convective, and radiative losses } \\
\text { from heated products: }\end{array}$ & $\begin{array}{l}\text { - Hot cokes } \\
\text { - Blast furnace slags }\end{array}$ \\
\hline Waste heat from air conditioners & \\
\hline
\end{tabular}

\subsection{Recommended Potential Applications of Waste Heat}

Different researchers recommended numerous potential applications of waste heat. The exhaust gas can be used in different applications depending on the level of its temperature. Exhaust gas at a very high level is used to heat up the combustion air for boilers using preheaters, and for furnaces, gas turbines, and ovens by using recuperators. It is also used to preheat the boiling feed water using economizer when its temperature level is medium. When it is at a low temperature level it is used to heat water and feedstock. Running absorption refrigeration systems for air conditioning is considered to be one type of waste heat potential application. Waste heat from heat pump systems, which is the main focus in this paper, can be used for water heating and drying simultaneously.

\subsection{Factors Influencing the Feasibility of Waste Heat Recovery}

The possibility of implementing an efficient and cost effective heat recovery system is affected by many factors. The evaluating process of the feasibility of waste heat recovery requires, at first, identifying the source of the heat and the steam which carries it. Heat quantity or heat content, heat temperature or quality, chemical composition of the steam, and the minimum allowed temperature are the most common factors that affect the feasibility of the recovery system. The heat content is defined as the amount of energy that is carried by the steam and it is a function of temperature and mass flow rate of the steam, while the term quality indicates to its benefits. The temperature difference between the heat source and sink is a very important factor as the temperature of the heat source must 
be higher than the temperature of the heat sink to enable the heat transfer process. This difference affects both the rate of heat transfer, and the efficiency of converting energy from one form to another. Meanwhile, the temperature of the waste heat source affects the selection of material in the heat exchangers as well as the recovery systems because of some chemical reactions, such as corrosion and oxidation, which accelerate dramatically with increasing temperature. Quality and quantity of the steam are not affected by the chemical composition of the steam as long as it does not include any fuel. But the composition effect is exclusively on the material selection, recovery process, and the thermal conductivity and heat capacity. Minimum allowed temperature to prevent chemical reactions like corrosion depends on the sort of fuel used. For instance, minimum temperature for hot exhaust gases from natural gas is about $120^{\circ} \mathrm{C}$, which differs from that for hot gases from coal or oil which is about $150^{\circ} \mathrm{C}$. Table 2 shows some typical waste heat temperatures from different sources at low, medium, and high level.

Table 2: Typical temperatures of waste heat from different sources at low, medium, and high level.

\begin{tabular}{lc}
\hline Source of Waste Heat & Typical Temperature $\left({ }^{\circ} \mathbf{C}\right)$ \\
\hline Aluminum Refining Furnace (High) & $650-760$ \\
Steel Heating Furnaces (High) & $925-1050$ \\
Open Hearth Furnace (High) & $650-700$ \\
Solid Waste Incinerators (High) & $650-1000$ \\
Glass Melting Furnaces (High) & $1000-1550$ \\
Steam Boiler Exhausts (Medium) & $230-480$ \\
Reciprocating Engine Exhausts (Medium) & $315-600$ \\
Drying and Baking Ovens (Medium) & $230-600$ \\
Annealing Furnace Cooling Systems (Medium) & $425-650$ \\
Air Conditioning and Refrigeration (low) & $32-88$ \\
Air Compressors (low) & $27-50$ \\
Cooling Water from Injection Molding Machines (low) & $32-88$ \\
\hline
\end{tabular}

\section{EXAMPLES OF WASTE HEAT RECOVERY EQUIPMENT USED FOR LOW, MEDIUM AND HIGH TEMPERATURE APPLICATIONS}

\subsection{Heat Exchangers (for Low Temperature Applications)}

The heat exchanger is a device used in different fields to exchange heat from hot fluids (usually waster or gases) to cold fluids. Various types of $\mathrm{HE}$ are nowadays commercially available such as gas- to-gas HE, gas-to-liquid HE, liquid-to-liquid HE. For waste heat recovering systems from air conditioners, heat exchangers transfer heat from the hot refrigerant to the cold water tank, as shown in Fig. 2. 


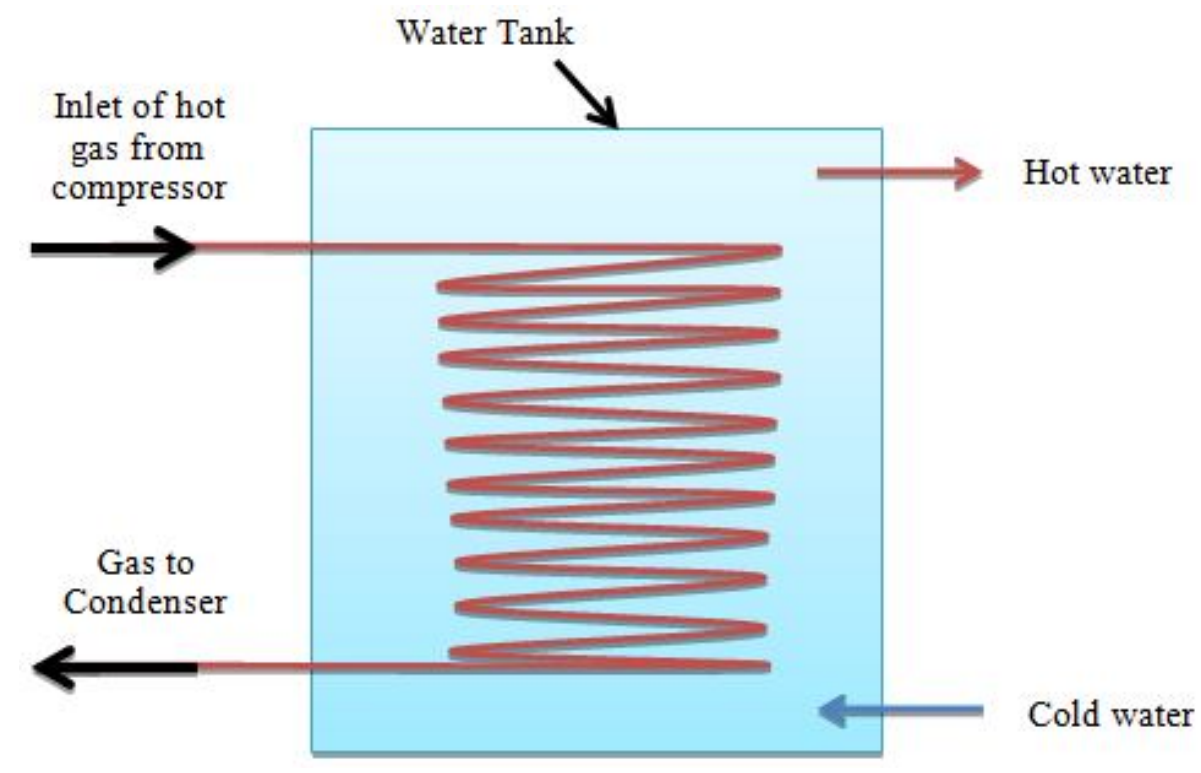

Fig. 2: Gas-to liquid heat exchanger for recovering waste heat from air conditioners.

\subsection{Recuperator (for Medium \& High Temperatures)}

The recuperator is a device usually used to recover the waste heat from the exhaust gas in medium and high temperature applications, like melting furnaces, radiant tube burners, and soaking ovens. These devices can be based on convection and radiation heat transfer process. Example of recuperator based radiation is shown in Fig. 3, where the hot gas comes through the inner duct and heat transfers by radiation to the cold air in the outer shell [5].

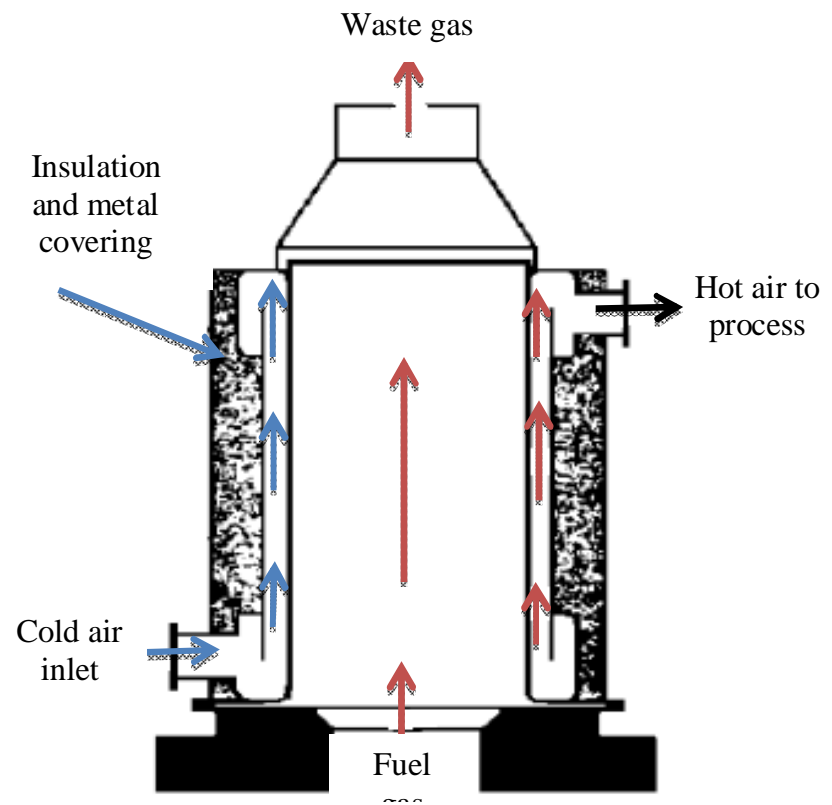

Fig. 3: Schematic of Recuperator based radiation sytem. 
Figure 4 shows an example of a recuperator-based convection heat transfer, where the hot wasted gas enters into tubes surrounded with cool fluid and the convection heat transfer process takes places resulting in producing heated fluid at high temperature.

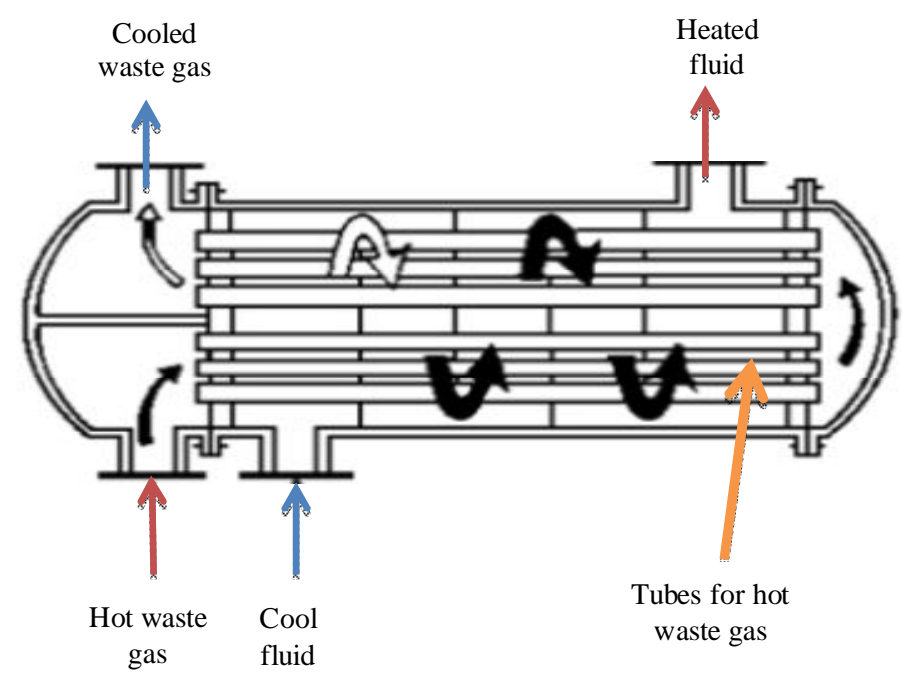

Fig. 4: Schematic of recuperator based convection system.

\subsection{Thermo-Electric Generator}

A huge amount of wasted heat is generated in thermal to electricity conversion systems. This wasted (energy) has relatively low temperature and energy density, so that it cannot be exploited to generate electricity using the conventional energy conversion cycles such as ORC, and Rankine. In this situation the direct conversion, without moving parts, of thermal energy to electrical energy may be the best alternative. The thermoelectric generator is a solid state device that converts thermal energy directly to electricity, and unlike the traditional heat engines it has no moving part and operates in a completely silent mode [6]. Such devices can be used to recover the wasted heat from the low temperature sources, such as air conditioners, in order to generate electricity instead of throwing it away. Physically, the principle of work of the thermoelectric generator is quite similar to that for solar cells, as shown in Fig. 5.

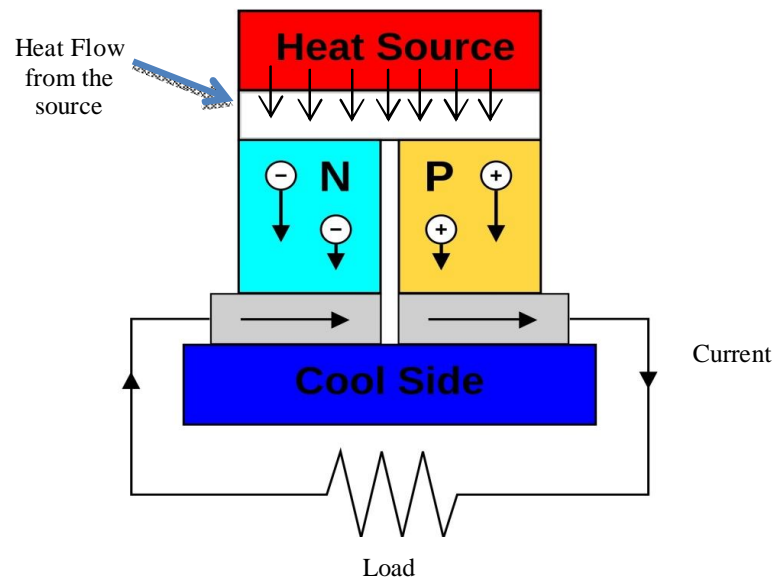

Fig. 5: Thermo-electric generator. 


\subsection{Water Heat Recovery Boiler}

The working principle of the water heat recovery boiler is similar to the normal water tube boiler, where the hot exhaust gases exchange heat with parallel tubes contain cold water. This leads to vaporize the water inside the tubes, and then it will be collected in the stream drum to be used for another application, as it is illustrated in Fig. 6, which represents schematic of a water heat recovery boiler.

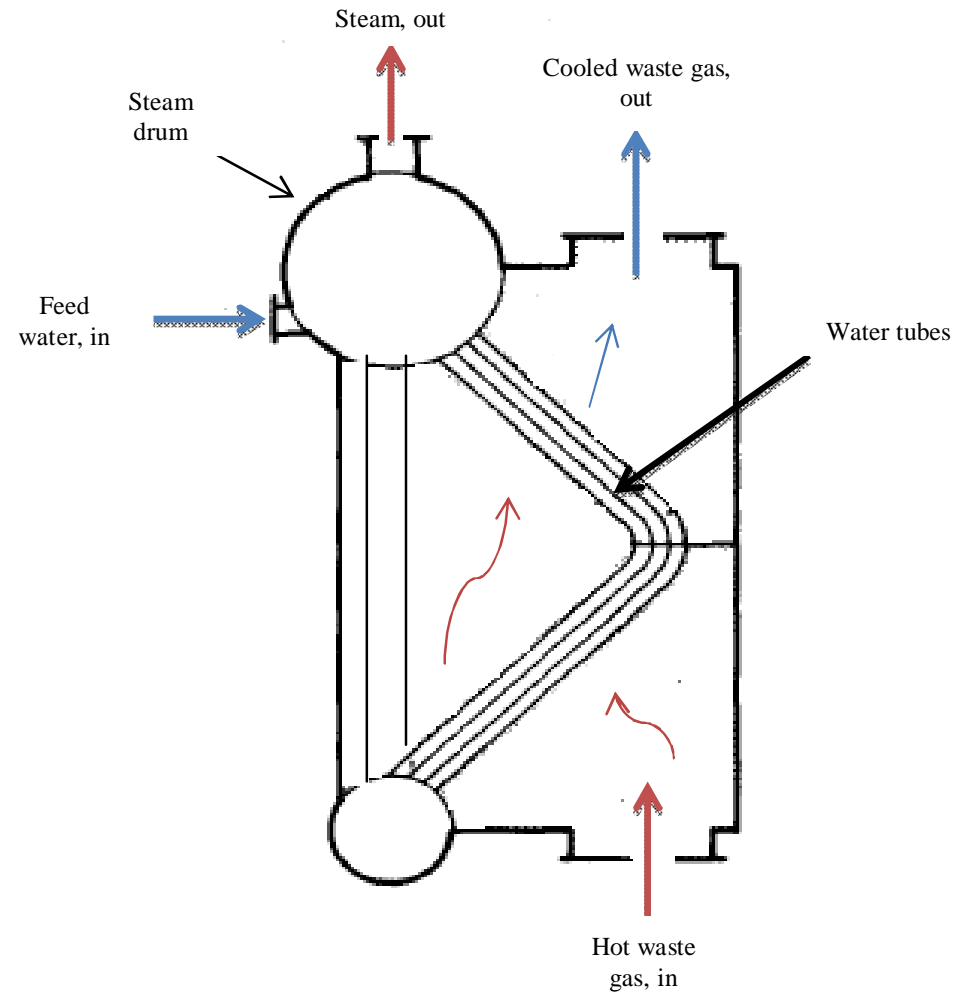

Fig. 6: Schematic of waste heat recovery boiler.

\section{HEAT PUMP (AIR CONDITIONER) AND HEAT RECOVERY TECHNOLOGIES}

The heat pump system is a vapor compression system consisting of four main components which are compressor, condenser, expansion device and an evaporator, as shown in Fig. 7. Figure 8 is the p-h (pressure-enthalpy) diagram of the conventional system [7]. These systems are designed in order to cool down the interior space by removing the heat from it and reject it into ambient air through the condenser. In the normal installation, heat rejection occurs directly to the ambient air, but recently many designations have been proposed by different researchers in order to recover the wasted heat to be used for different applications such as water heating, drying, and desalination, especially in buildings that run air-conditioners all day such as hotels and hospitals according to Hawlader [8]. Figure 9 represents as example of a heat pump system with heat recovery system used for water heating for domestic applications. 


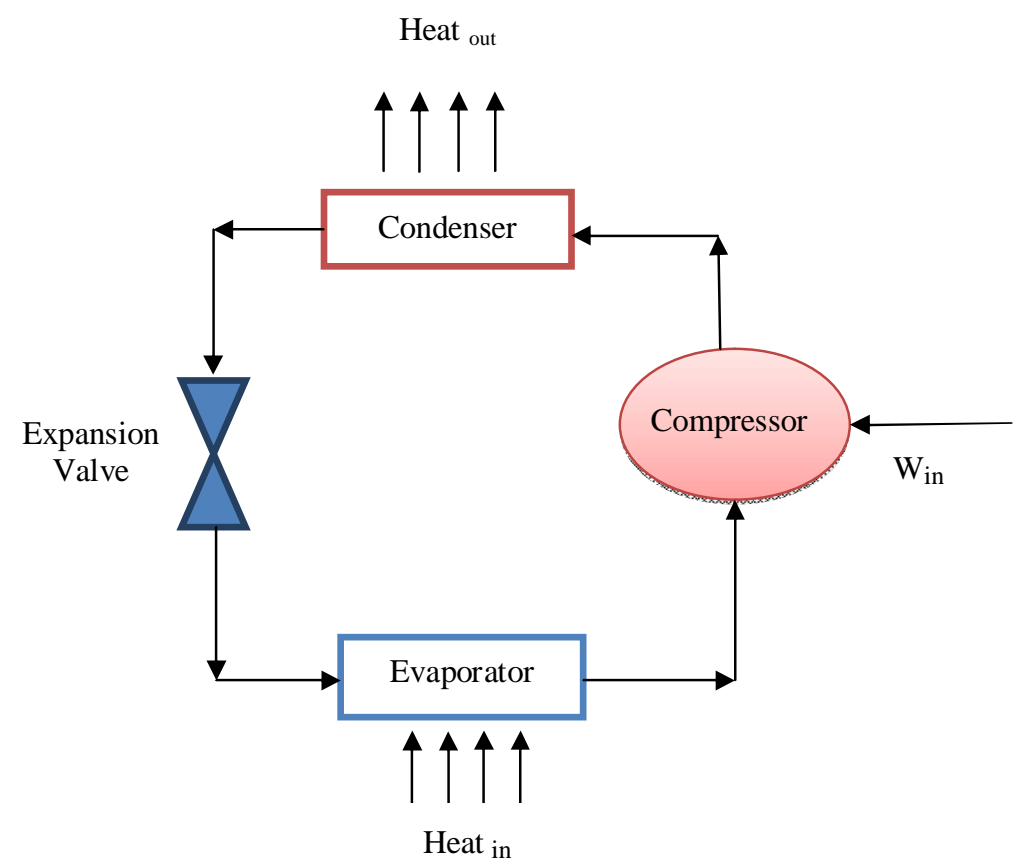

Fig. 7: Schematic of vapor compression air conditioning system.

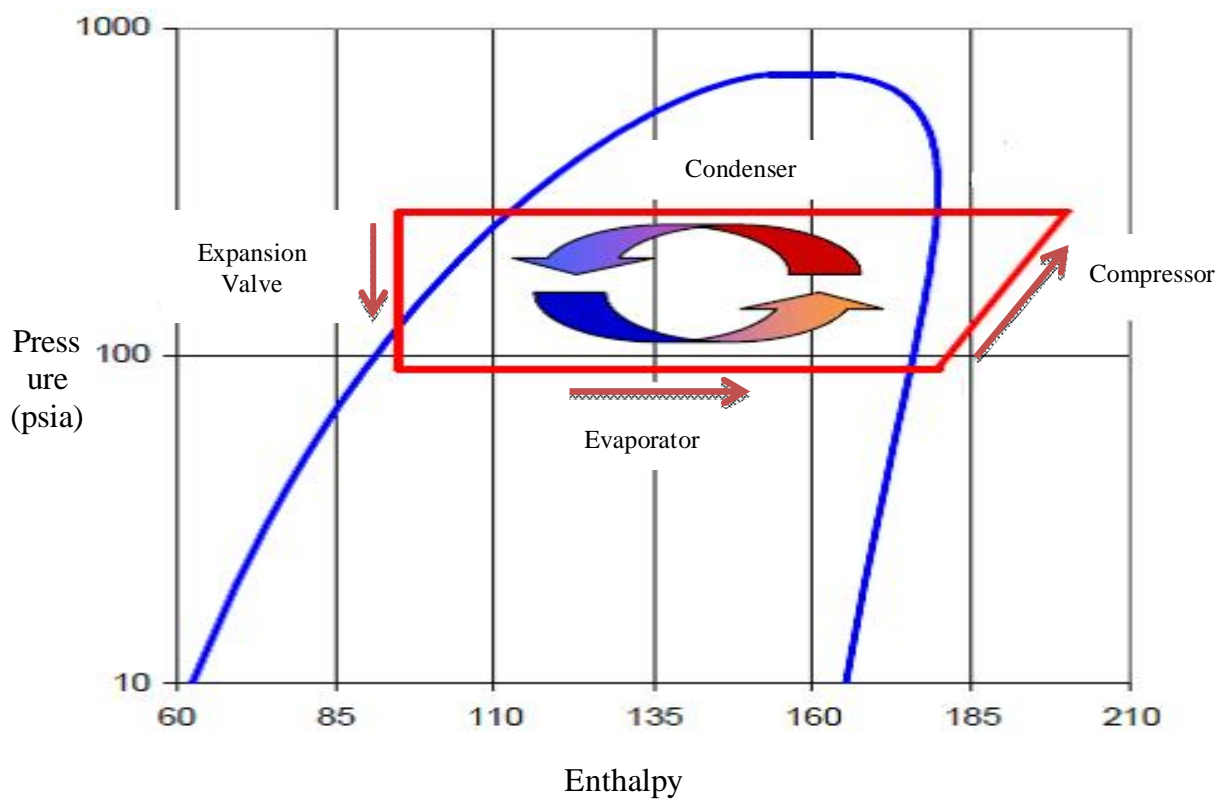

Fig. 8: P-h diagram for conventional heat pump systems [7].

Wasted heat is any source of rejected heat, which may include gas, solid, and liquid, can be partially or fully reused or recovered economically. Practically, wasted heat from air conditioners or heat pumps is not only the heat that has to be removed from the environment, it also includes the heat added to the refrigerant from the compression process [9]. The prediction of the amount of wasted or dissipated heat from the air 
conditioners is a daunting task because the space load and the outside conditions vary from day to day during the season as well as the year. For example, the amount of wasted heat from a 20 ton air conditioner operating at full capacity may reach 24 tons of heat, while same units having same specifications may reject only 13 tons of heat or less at $30 \%$ capacity [9]. According to Hawlader [10] in tropical countries such as Malaysia, air conditioners are consuming more than half of the building energy, and every $1 \mathrm{~kW}$ of the consumed electricity by an air conditioner leads to about $4 \mathrm{~kW}$ of thermal energy at $85^{\circ} \mathrm{C}$ being thrown into the atmosphere, which contributes to global warming. Normally, when the temperature of wasted heat is high, the recovery system will be more cost effective and of higher quality. Many benefits could be achieved from recovering the wasted heat such as reducing the cost of the process by increasing the energy productivity, reduce the pollution, reduction in equipment size, and reduction in auxiliary energy consumption.

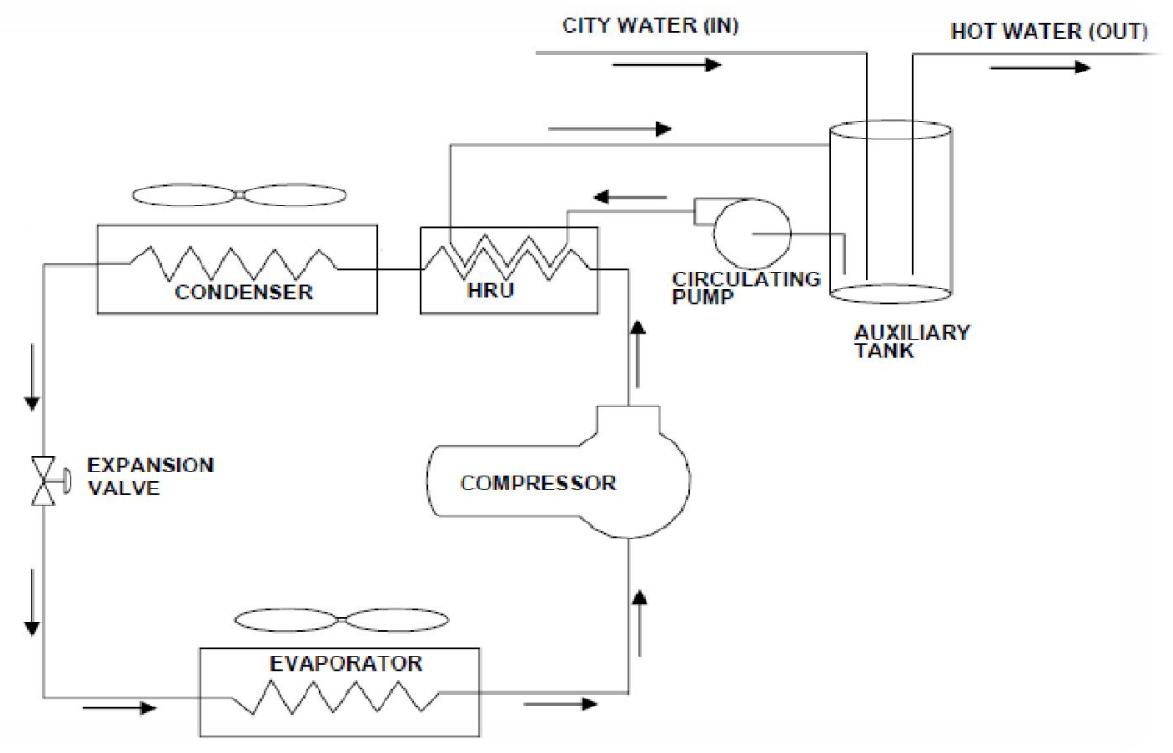

Fig. 9: Example of heat pump system with heat recovery system for water heating.

\section{SOLAR ASSISTED HEAT PUMP (SAHP) TECHNOLOGIES}

The solar assisted heat pump system is a conventional heat pump system where solar energy is the main heat source instead of/ besides the electrical energy, as shown in Fig. 10. This system usually consists of a compressor, heat exchanger, evaporator (usually flat plat solar collector), and expansion valve [11]. Many designs of SAHP are nowadays available in the market which differ slightly or sometimes fundamentally from one another. The main differences are in the type and size of the heat source, heat storage system, and solar collector type. These systems usually use flat plate solar collectors with conventional refrigerants such as R134a. Recently, many researchers are moving toward embracing and using $\mathrm{CO}_{2}$ as refrigerant in SAHP systems because of environmental issues such as ozone depletion, and global warming. Besides that, $\mathrm{CO}_{2}$ has thermodynamic properties which enable it to be competitive and most promising alternative of conventional refrigerants [12]. Using $\mathrm{CO}_{2}$ in SAHP systems makes the system work under the transcritical thermodynamic cycle not the traditional vapor compression cycle. Carbon dioxide heat pump systems will be detailed more in the next section. 


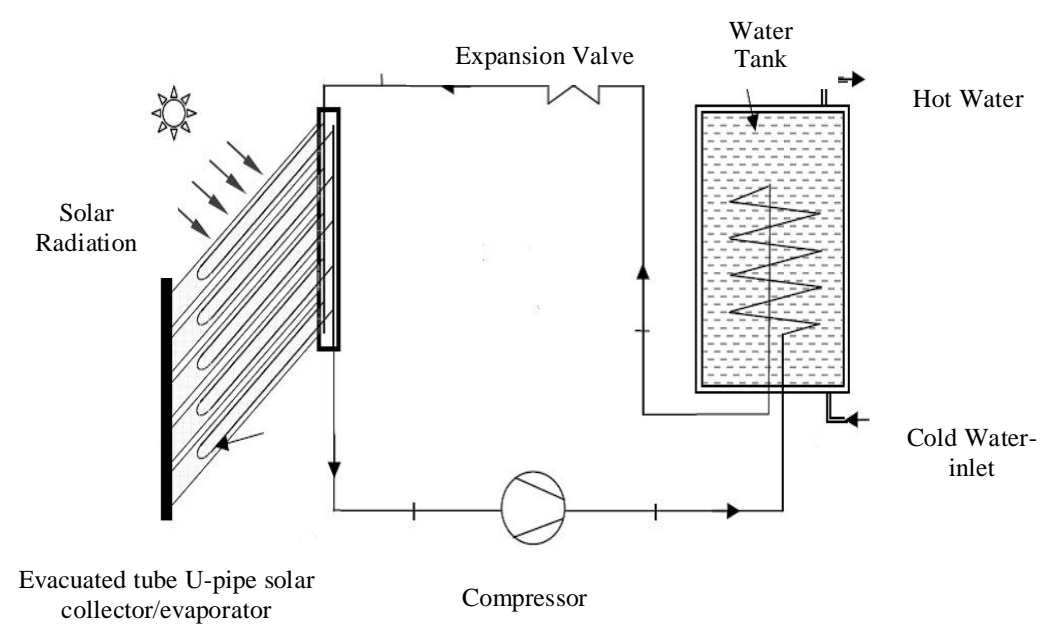

Fig. 10: Diagram of SAHP system for water heating.

\section{CARBON DIOXIDEAS REFRIGERANT IN HEAT PUMP SYSTEMS}

Refrigerant, in such systems, is considered the blood of the system. It is very important to choose the proper refrigerant in SAHP systems because the entire system will be affected by it [13]. According to Maina and Huan [14], the most important factors that must be taken into account in the selection of the refrigerant in the heat pump systems are safety, reliability, cost, heat transfer properties, performance, and environmental acceptability. Carbone dioxide is inexpensive, readily available, odorless at low concentrations, compatible with materials, and not a corrosive refrigerant [14], non-toxic, and non-flammable [15].

The two most popular refrigerants used in the past are ammonia and carbon dioxide. Ammonia was stopped being used by the industry because it is toxic and harmful. Carbon dioxide was stopped because of the advent of the fluorocarbon chemicals, it requires extremely high pressure (more than 73.8 bar), so that the compressor outlet temperature is also very high $\left(160^{\circ} \mathrm{C}\right)$, which will cause capacity and COP loss at high heat rejection temperature [16]. The only solution that was proposed to solve the capacity and COP loss issue was to utilize two-stage cycles. This was because the sealing technology was not high and advanced at that time.

Fluorocarbon chemicals are causing air, water, and land pollution. They also cause global warming and ozone depletion whereas natural refrigerant particularly $\mathrm{CO}_{2}$ has zero global warming potential. Due to that many researchers reconsidered the use of natural gas in particularly $\mathrm{CO}_{2}$ as an alternative refrigerant because of its thermodynamic properties, non-toxicity, and non-flammability [15]. Depending on the study that conducted by Neksa in 2004, $\mathrm{CO}_{2}$ (R744) is the most attractive refrigerant for heat pumps water heaters, HP for space conditioning, HP for dryers, and commercial refrigeration. According to Stene [17], carbon dioxide heat pump water heater systems are the most attractive and promising technology for flats and apartments, nursing homes, hotels, sport centers, and hospitals.

High pressure issue of $\mathrm{CO}_{2}$ could be a demerit for it, but it is no longer a problem with the development of advanced sealing technology. Therefore, high compressor outlet temperature is not a disadvantage, because it can provide hot water near to the boiling 
point (sometimes more than $90^{\circ} \mathrm{C}$ ) and cooling near to $50^{\circ} \mathrm{C}$ [16]. This water could be used in different applications such as cooling space, drying, water heating, and desalination of seawater simultaneously if the system was properly designed. So that it would be more prudent to reconsider and reuse Carbon Dioxide as a promising alternative refrigerant in SAHP systems.

Carbon dioxide driven SAHP systems could provide hot water with temperature more than $90^{\circ} \mathrm{C}$ without any operational problems, as shown in Fig. 11 which represents the temperature-entropy diagram (T-S) of the transcritical $\mathrm{CO}_{2}$ cycle and shows the temperature of the $\mathrm{CO}_{2}$ gas through the transcritical thermodynamic cycle [16]. Laipradit et al. [18] simulated the performance of a carbon dioxide heat pump system for water heating. The systems consisted of compressor, gas cooler, expansion valve, and evaporator (finned tube cross flow heat exchanger type). The result of the computer simulation showed that the coefficient of performance (COP) was from 2 to 3 for $4 \mathrm{~kW}$ compressor, $10 \mathrm{~kW}$ gas cooler, and $6 \mathrm{~kW}$ evaporator. The water temperature was found to be 50 to $60^{\circ} \mathrm{C}$ under these conditions. It is also concluded that the most suitable mass flow ratio water to refrigerant is 1.2 and 2.2 for producing hot water above $60^{\circ} \mathrm{C}$.

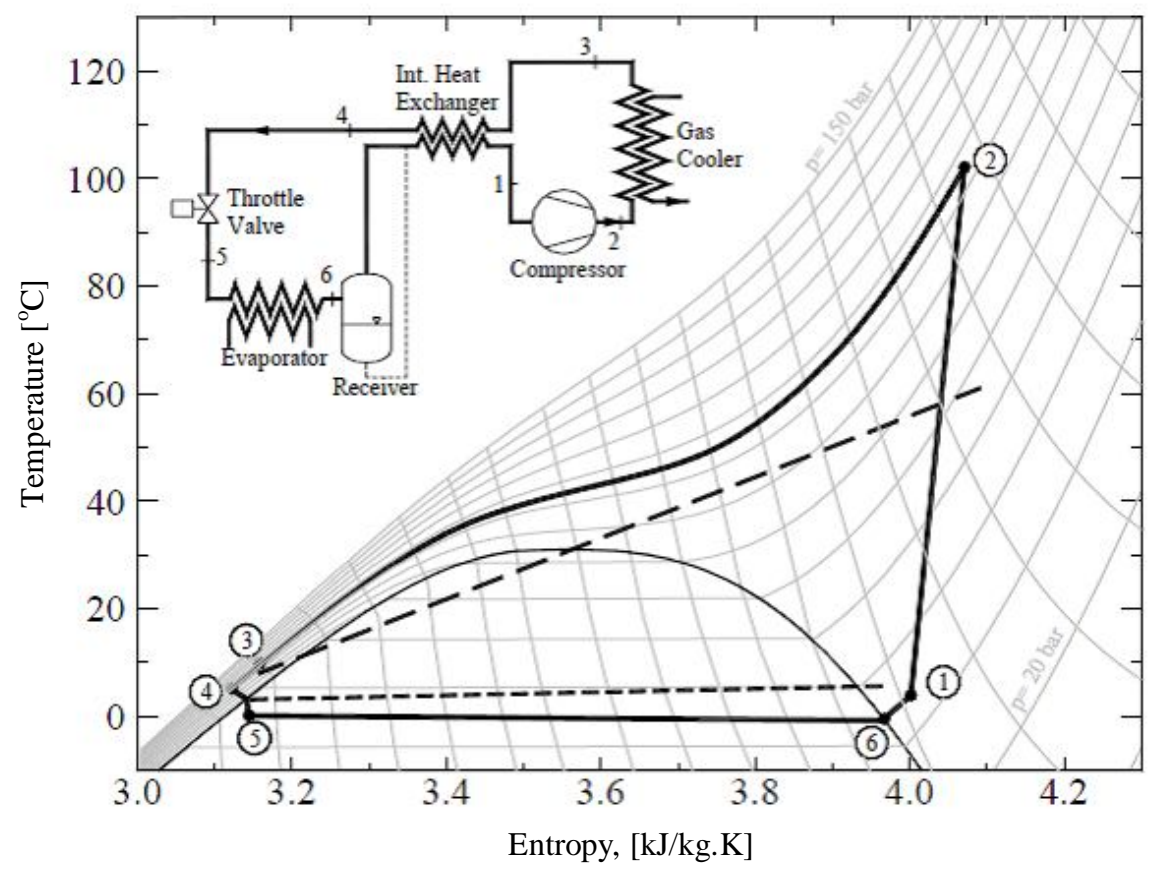

Fig. 11: T-S diagram of the $\mathrm{CO}_{2} \mathrm{HP}$ with WHR system used for water heating applications [15].

\section{CONCLUSION}

Waste heat recovery technologies have been recently recommended and introduced by many researchers worldwide as a solution for energy conservation to reduce global warming and air pollution. The amount of waste heat from heat pump systems can be huge especially in tropical countries such as Malaysia, where air conditioners are operated almost for the entire day as well as throughout the year. Waste heat recovery technology from air conditioners to produce domestic hot water and drying could be an excellent solution if implemented in hospitals, hotels, halls, and apartments. Refrigerants in such systems are considered the most important factor that affects the system efficiency. 
Carbon dioxide driven heat pump systems have been tested worldwide, and recommended as the best alternative instead of traditional refrigerants because of its high volumetric capacity and, its ability to provide hot water close to the boiling point as well as efficient drying.

\section{REFERENCES}

[1] Senda FM. (2012) Aspects of waste heat recovery and utilization (WHR\&U) in Pebble Bed Modular. Master of Science thesis, the University of Stellenbosch, South Africa.

[2] Pathania A, Mahto D. (2012) Recovery of engine waste heat for reutilization in air conditioning system in an automobile: An investigation. Global Journal of Researches in Engineering, 12(1).

[3] International Energy Agency Heat Pump Program. (2012) Heat pump and heat recovery technology.www.heatpumpcentre.org/en/aboutheatpumps/Sidor/default.aspx

[4] Reay DA. (1979) Heat recovery systems, a directory of equipment and techniques. E. \& F. N. Spon: London.

[5] US Department of Energy. (2008) Heat recovery: Technology and opportunities in US Industry.

[6] Bitschi A. (2009) Modelling of thermoelectric devices for electric power generation. Doctor of Sciences Dissertation, Swiss Federal Institute of Technology Zurich (ETH ZURICH).

[7] Momin G, Deshmukh SR, Deshmukh MT, Chavan PT, Choudhari PP. (2014) COP enhancement of domestic refrigerator by recovering heat from the condenser. International Journal of Research in Advent Technology, 2(5):2321-9637.

[8] Hawlader, MNA. (2013) Utilization of solar energy and waste heat for water heating, drying and desalination of seawater. Paper presented in (ICMIME2013), 1-3 November, 2013, RUET, Rajshahi, Bangladesh.

[9] Jarnagin RE. (2008) Heat recovery from air conditioning units. University of Florida; Florida Cooperation Extention Service. Fact Sheet EES-26. Retrived on 10 October 2015 from http://www.wec.ufl.edu/extension/gc/harmony/documents/eh126.pdf.

[10] Hawlader MNA. (2014) Water heating and drying using solar energy and waste heat from air conditioners. Keynote Paper presented in International Symposium on Green and Sustainable Technology ISGST 2014, UTAR Perak Campus, Malaysia, Sept. 30- Oct.3.

[11] Islam MR, Sumathy K. (2013) Carbon dioxide driven solar-assisted heat pump water heating System: A theoretical analysis. Int. Res. J. Env. Sciences, 2(10):77-92.

[12] Austin BT, Sumathy K. (2011) Transcritical carbon dioxide heat pump systems: A review. Renewable and Sustainable Energy Reviews, 15:4013-4029.

[13] Zakaria MA (2010) A solar assisted heat pump system for desalination. PhD thesis, National University of Singapore, Singapore.

[14] Maina P, Huan Z. (2013) Effect of refrigerant charge in the output of $\mathrm{CO}_{2}$ heat pump. African J. Sci. Tech. Innov. Dev., 5(4): 303-311

[15] Neksa P. (2004) $\mathrm{CO}_{2}$ as refrigerant for systems in transcritical operation principles and technology status. A paper presented in AIRAH's 2004 natural refrigerants conference, Museum of Sydney, July $28-2004$.

[16] Sakar J. (2005) Transcritical carbon dioxide heat pump for simultaneously cooling and heating. Ph. D. thesis, Indian Institute of Technology Kharagpur, India.

[17] Stene J. (2008) High efficiency $\mathrm{CO}_{2}$ heat pump water heater systems for residential and nonresidential buildings. Retrieved on 20 October 2014 from http://www.r744.com/assets/link/R744com_CO2-HPWH_2008.pdf

[18] Laipradit P, Tiansuwan J, Kiatsiriroat T, Aye L. (2008) Theoretical performance analysis of heat pump water heaters using carbon dioxide as refrigerant. Int. J. Energy Research, 32:356-366. 